\title{
Ensaio sobre uma execução penal mais racional e redutora de danos
}

\author{
Rodrigo Duque Estrada Roig*
}

\begin{abstract}
RESUMO
O presente artigo examina a questão da execução penal sob o prisma da limitação racional do poder punitivo estatal. Assim, busca-se realizar uma leitura das normas disciplinadoras da execução penal à luz da Constituição Federal, orientando-se no sentido de uma redução de danos na prática penitenciária.
\end{abstract}

PALAVRAS-CHAVE: Execução penal; Redução de danos; Limitação do poder punitivo estatal.

\begin{abstract}
This article examines the issue of criminal enforcement through the prism of rational limitation of state's punitive power. Thus, we seek to achieve a reading of the norms concerning to criminal enforcement in light of the Federal Constitution, orienting itself towards a harm reduction in prison practices.
\end{abstract}

KEYWORDS: Criminal enforcement, Harm reduction, Limitation of state's punitive power.

\section{Introdução}

Os vinte e cinco anos da edição da Lei de Execução Penal (LEP - Lei n. 7.210/1984) trazem sensações bastante díspares entre juristas e profissionais diretamente vinculados ao sistema penitenciário. Apontarei duas das principais impressões. Alguns juristas e profissionais enxergam na LEP uma lei extremamente inovadora, que se integralmente cumprida teria o poder de solucionar os problemas que atormentam a execução da pena no Brasil. É o que denominamos "positivismo romântico". Outros entendem ser a Lei de Execução Penal branda e liberal, merecedora assim de reformas capazes de torná-la um instrumento de eficaz defesa da sociedade frente à periculosidade característica dos delinqüentes. É o “ofuscado e perseverante positivismo etiológico".

\footnotetext{
* Defensor Público do Estado do Rio de Janeiro. Professor de Direito Penal e Execução Penal. Autor dos livros "Direito e Prática Histórica da Execução Penal no Brasil" (Editora Revan, 2005), "Direito Penal 2 - parte especial" (Editora Saraiva, 2007). e "Direito Penal 3 - legislação penal especial" (Editora Saraiva, 2009). Graduado pelo $69^{\circ}$ Curso Internacional de Criminologia (Buenos Aires, Argentina). Especialista em Processo Penal (Investigação e Prova) pela Universidad Castilla-La-Mancha (Toledo, Espanha). Mestre em Direito Penal e Criminologia (Ciências Penais) pela Universidade Cândido Mendes. Doutorando em Direito Penal pela Universidade do Estado do Rio de Janeiro. Ex-membro da Comissão de Estudos Penitenciários (tendentes à Criação do Banco de dados sobre população carcerária nacional) do Conselho Nacional de Justiça (CNJ). ExCoordenador da Comissão Nacional de Defensores Públicos em Execução Penal do Conselho Nacional dos Defensores Públicos Gerais (CONDEGE). Membro da Comissão Nacional de Apoio às Penas e Medidas Alternativas (CONAPA) do Ministério da Justiça. Membro do Conselho Nacional de Política Criminal e Penitenciária (CNPCP) - Ministério da Justiça.
} 
Ao contrário do que prescreve a prudência, nos colocamos no fogo cruzado entre essas "facções messiânicas do positivismo" para sustentar uma postura pragmático-redutora da execução penal, de um lado descrente das faculdades miraculosas dos dispositivos da LEP, sem que estejam acompanhados de efetivas medidas para o implemento de seus comandos, e que de outro vê a legislação executivo-penal não como ferramenta de prorrogação do poder punitivo para além do processo de conhecimento, mas como instrumento de limitação racional desse poder, capaz de reduzir ao máximo os danos que a experiência penitenciária causa ao indivíduo e à sociedade.

A visão pragmático-redutora da execução penal parte fundamentalmente de duas premissas: por um lado considerar subsistentes somente os dispositivos efetivamente recepcionados pela Constituição, afastando consequentemente aqueles eivados de inadequação constitucional. Por outro lado, aportar para a legislação e prática penitenciárias todos os instrumentos redutores do poder punitivo preconizados pela Constituição de 1988, Código Penal, Código de Processo Penal e pelos Tratados e Convenções internacionais sobre o tema. Acreditamos ser esta uma útil forma de ruptura com o "isolamento antidemocrático" sofrido pela Lei de Execução Penal ao longo desse quarto de século.

A efetividade desse novo paradigma da execução penal depende evidentemente de vontade política, mas também, essencialmente, da revisão e introdução de alguns conceitos penais. Neste escopo, apresentamos a seguir algumas proposições, de forma breve e sem a pretensão de esgotar o tema.

\section{Direitos não atingidos na execução}

Apesar de dotados de uma cristalina obviedade, alguns dispositivos precisam ser exaustivamente lembrados a determinados operadores do direito. Caso contrário, são simplesmente olvidados. E vilipendiados. Um deles consiste no art. $3^{\circ}$ da $\mathrm{LEP}^{1}$, que assegura ao condenado e ao internado todos os direitos não atingidos pela sentença ou pela lei.

Dentre tais direitos não atingidos pela sentença ou pela lei podemos destacar os direitos à vida, igualdade, segurança, propriedade (art. $5^{\circ}$ caput, $\mathrm{CR}$ ), inexigibilidade de fazer

1 No mesmo sentido aponta o art. 38 do CP: "O preso conserva todos os direitos não atingidos pela perda da liberdade, impondo-se a todas as autoridades o respeito à sua integridade física e moral". Relevante também o disposto no item 57 das Regras Mínimas para o Tratamento de Prisioneiros da ONU: "A prisão e outras medidas cujo efeito é separar um delinqüente do mundo exterior são dolorosas pelo próprio fato de retirarem do indivíduo o direito à autodeterminação, privando-o da sua liberdade. Logo, o sistema prisional não deverá, exceto por razões justificáveis de segregação ou para a manutenção da disciplina, agravar o sofrimento inerente a tal situação". 
ou deixar de fazer alguma coisa senão em virtude de lei (art. $5^{\circ}$, II), não submissão à tortura nem a tratamento desumano ou degradante (art. 5\%, III), liberdade de manifestação do pensamento (art. $\left.5^{\circ}, I V\right)$, inviolabilidade da liberdade de consciência e de crença (art. $\left.5^{\circ}, \mathrm{V}\right)$, inviolabilidade da intimidade, a vida privada, a honra e a imagem (art. $5^{\circ}, \mathrm{X}$ ), inviolabilidade do domicílio (art. $5^{\circ}, \mathrm{XI}$ ), inviolabilidade do sigilo da correspondência ( $\left.\operatorname{art} .5^{\circ}, \mathrm{XII}\right)$, liberdade de associação para fins lícitos (art. 5 XVII), direito de petição aos Poderes Públicos em defesa de direitos ou contra ilegalidade ou abuso de poder (art. $5^{\circ}$, XXXIV), individualização da pena (art. $5^{\circ}$, XLVI), devido processo legal (art. $5^{\circ}$, LIV), contraditório e ampla defesa (art. $5^{\circ}$, LV), assistência da família e de advogado (art. 5, LXIII), direito à identificação dos responsáveis por sua prisão (art. $5^{\circ}$, LXIV), indenização pela prisão além do tempo fixado na sentença (art. $5^{\circ}, \mathrm{LXXV}$ ), razoável duração do processo (art. $5^{\circ}$, LXXVIII), direito ao trabalho (arts. $6^{\circ}$ e $7^{\circ}$ da CR).

Aos que possuem por costume acender velas ao poder punitivo, soa como verdadeiro sacrilégio a pluralidade de direitos conferidos pela Constituição aos apenados. Inimaginável, ainda, que existam mais a serem respeitados. Pois há, todos previstos no art. 41 da LEP².

Chama mais atenção, porém, a restrição contida no art. 41, parágrafo único, da LEP. Por expressa previsão deste dispositivo, poderão ser suspensos ou restringidos mediante ato motivado do diretor do estabelecimento os direitos de proporcionalidade na distribuição do tempo para o trabalho, de visita do cônjuge, da companheira, de parentes e amigos e o contato com o mundo exterior por meio de correspondência escrita, da leitura e de outros meios de informação.

Emblemático este dispositivo. Uma interpretação lógica nos conduz à conclusão de que, por restringir somente determinados direitos, a contrario sensu os demais não podem sofrer qualquer espécie de suspensão ou restrição, seja por parte do juiz, seja por parte da autoridade penitenciária ${ }^{3}$. Não é o que verificamos na prática, no entanto.

No tocante aos direitos dos presos, alguns merecem nova reflexão.

\footnotetext{
${ }^{2}$ Os direitos previstos são os de alimentação suficiente e vestuário, atribuição de trabalho e sua remuneração, Previdência Social, constituição de pecúlio, proporcionalidade na distribuição do tempo para o trabalho, o descanso e a recreação, exercício das atividades profissionais, intelectuais, artísticas e desportivas anteriores, desde que compatíveis com a execução da pena, assistência material, à saúde, jurídica, educacional, social e religiosa, proteção contra qualquer forma de sensacionalismo, entrevista pessoal e reservada com o advogado, visita do cônjuge, da companheira, de parentes e amigos em dias determinados, chamamento nominal, igualdade de tratamento salvo quanto às exigências da individualização da pena, audiência especial com o diretor do estabelecimento, representação e petição a qualquer autoridade, em defesa de direito, contato com o mundo exterior por meio de correspondência escrita, da leitura e de outros meios de informação que não comprometam a moral e os bons costumes e, por fim, atestado de pena a cumprir, emitido anualmente, sob pena da responsabilidade da autoridade judiciária competente.

${ }^{3}$ No mesmo sentido, MIRABETE, Julio Fabbrini. Execução Penal. $9^{a}$ ed., São Paulo: Ed. Atlas, 2000, p.126.
} 


\subsection{Direito de correspondência}

O primeiro deles é o direito ao contato com o mundo exterior por meio de correspondência escrita. Segundo entendimento dominante, a exceção feita pelo parágrafo único do art. 41 da LEP assegura à administração penitenciária o direito de suspender ou restringir a correspondência dos detentos, por ato motivado, sempre que entender necessário. O próprio Supremo Tribunal Federal já se pronunciou no sentido de que "a administração penitenciária, com fundamento em razões de segurança pública, de disciplina prisional ou de preservação da ordem jurídica, pode, sempre excepcionalmente, e desde que respeitada a norma inscrita no art. 41, parágrafo único, da Lei n. 7.210/84, proceder à interceptação da correspondência remetida pelos sentenciados, eis que a cláusula tutelar da inviolabilidade do sigilo epistolar não pode constituir instrumento de salvaguarda de práticas ilícitas" (STF, HC 70814/SP).

Uma postura pragmático-redutora da execução penal, que ora se defende, traz por outro lado uma distinta interpretação sobre o direito de correspondência dos presos. Inicialmente, em atenção ao princípio da legalidade, não bastaria para a restrição da inviolabilidade da correspondência uma faculdade legal genérica, tal como a estabelecida no art. 41, parágrafo único, da LEP. Necessária, ao invés, a edição de uma lei que determine em quais hipóteses e com quais fundamentos tal restrição pode ser realizada 4 .

Ainda que se admita uma faculdade não taxativa de restrição ou suspensão do direito de comunicação dos presos com o mundo exterior, tal faculdade deve ser entendida tãosomente como a possibilidade de impedimento ou limitação do fluxo das mesmas, não podendo se confundir com a devassa e leitura do conteúdo das correspondências.

Cumpre ainda ressaltar que a Constituição Federal, ao estabelecer as garantias de inviolabilidade da intimidade (art. $5^{\circ}, \mathrm{XI}$ ) e do sigilo da correspondência (art. $5^{\circ}, \mathrm{XII}$ ), tratou de assegurá-las a todos os seres humanos, sem realizar qualquer distinção quanto aos presos. Se a própria Constituição não realizou a devida limitação, não pode esta advir de uma norma

\footnotetext{
${ }^{4}$ Esse é o entendimento da Corte Suprema de la Nación argentina, que no julgamento do caso "Dessy" estabeleceu critérios para uma restrição válida da correspondência dos reclusos: "a) que haya sido dictada una ley que determine en qué casos y con qué justificativos podrá procederse a tomar conocimiento del contenido de dicha correspondencia; b) que la ley esté fundada en la existencia de un sustancial o importante objetivo del Estado, desvinculado de la supresión de la inviolabilidad de la correspondencia epistolar y de la libertad de expresión; c) que la aludida restricción resulte un medio compatible con el fin legítimo propuesto y, d) que dicho medio no sea más extenso que lo indispensable para el aludido logro". Nesse sentido, cf. FELLINI, Zulita (Dir.). Derecho de ejecución penal. 1ª ed., Buenos Aires: Hammurabi, 2006, p. 156.
} 
infraconstitucional (anterior), ou mesmo de seu intérprete. Deve a Lei de Execução Penal, nesse ponto, sofrer a necessária adequação interpretativa constitucional.

Assim é que, em caso de fundada suspeita em relação a determinada correspondência recebida ou remetida, é assegurado à autoridade tão somente o direito de retê-la, entregando-a ao preso no momento de sua soltura. A violação, por parte de agentes públicos, do conteúdo da correspondência recebida ou enviada pelos presidiários constitui, a nosso ver, crime de abuso de poder (art. 30, "c" da Lei n. 4.898/65).

\subsection{Voto do preso definitivamente condenado}

Outro direito de extrema complexidade é o voto do preso definitivamente condenado. O inciso III do art. 15 da CF prevê a possibilidade de perda ou suspensão de direitos políticos em caso de condenação criminal transitada em julgado, enquanto durarem seus efeitos. Atualmente ainda predomina o entendimento de que o preso definitivamente condenado está impossibilitado de votar, uma vez que a expressão "direitos políticos" do art. 15 abrange não apenas a elegibilidade, mas também o direito de votar. Tal posição aponta, como fundamento, a necessidade de se conferir ao art. 15, III, um "mínimo de eficácia".

Entendimento diverso sustenta a possibilidade de voto do preso definitivamente condenado. Inicialmente argumentou-se que a expressão "direitos políticos" do art. 15 da CF não teria delimitado o objeto da proibição, mostrando-se vaga. Ante a vagueza do art. 15 da $\mathrm{CF}$, caberia à Lei Complementar n. 64/90 (que complementa o art. $14 \S 9^{\circ}$ da $\mathrm{CF}$ ) dar o real alcance à possibilidade de voto. Como os efeitos da Lei Complementar n. 64/90 se restringem apenas à inelegibilidade (e somente em função de determinados crimes) ${ }^{5}$, o direito de voto não estaria alcançado.

A par desse argumento inicial, atualmente podemos formular outros fundamentos. $\mathrm{O}$ primeiro deles parte do pressuposto de que o artigo 15, inciso III, da CF, por representar uma limitação a um direito fundamental (direito político), deve sofrer uma interpretação restritiva. Assim, diante da falta de clareza do referido dispositivo constitucional, a limitação ali prevista não deve englobar o direito de voto.

Outro fundamento reside no fato de que a Constituição admite que a legislação infraconstitucional estabeleça a perda ou a suspensão dos direitos políticos na hipótese de

\footnotetext{
5 Art. $1^{\text {o }}$ da LEI COMPL. 64/90. São inelegíveis: I - para qualquer cargo: e) os que forem condenados criminalmente, com sentença transitada em julgado, pela prática de crime contra a economia popular, a fé pública, a administração pública, o patrimônio público, o mercado financeiro, pelo tráfico de entorpecentes e por crimes eleitorais, pelo prazo de 3 (três) anos, após o cumprimento da pena.
} 
“condenação criminal transitada em julgado, enquanto durarem seus efeitos". A lei ordinária (artigo 92, do CP), por sua vez, limita-se a estabelecer como efeito extrapenal da sentença penal condenatória apenas a perda do mandato eletivo (inciso I). Não haveria qualquer menção à perda ou suspensão do direito de votar, não sendo legítima tal restrição ${ }^{6}$.

Por fim, são uníssonos os instrumentos internacionais de tutela dos direitos humanos, quando dispõem, por exemplo, que "toda pessoa tem o direito de tomar parte no governo de seu país diretamente ou por intermédio de representantes livremente escolhidos" (artigo XXI, 1, da Declaração Universal dos Direitos Humanos) ou que "todos os cidadãos devem gozar dos seguintes direitos e oportunidades: a) de participar da condução de assuntos públicos, diretamente ou por meio de representantes livremente eleitos; b) de votar e ser eleito em eleições periódicas, autênticas, realizadas por sufrágio universal e igualitário e por voto secreto, que garantam a livre expressão da vontade dos eleitores; e c) de ter acesso, em condições gerais de igualdade, às funções públicas de seu país" (artigo 23 da Convenção Americana de Direitos Humanos).

Sobre o tema, encontra-se em tramitação a proposta de emenda constitucional $\mathrm{n}$. 65/2003 que revoga o inciso III do art. 15 da CF e acrescenta no rol de votantes facultativos do art. 14 da CF os sujeitos à condenação criminal transitada em julgado, enquanto durarem seus efeitos (atualmente, analfabetos, maiores de setenta anos e maiores de dezesseis e menores de dezoito anos possuem voto facultativo). Apenas a inelegibilidade dos presos definitivamente condenados é mantida.

A justificação da proposta de emenda encarna perfeitamente a visão pragmáticoredutora da execução penal que postulamos, ao dispor que a suspensão dos direitos políticos, por condenação criminal transitada em julgado, impõe ao presidiário uma pena adicional, além da privação da liberdade. A Perda da liberdade, esclarece a proposta, deve se circunscrever tão-somente à privação da liberdade, não significando de modo algum a perda da cidadania. Tal postura é de fundamental importância para "ampliar as condições para o exercício de cidadania dos encarcerados brasileiros" e para "humanizar o cumprimento da pena e acenar com a expectativa de melhores condições de vida para os egressos do sistema penitenciário".

\footnotetext{
${ }^{6}$ Nesse sentido, cf. ALMEIDA, Angélica de Maria Mello de. Notas sobre o Direito de Votar do Preso. In: Boletim da Associação dos Juízes para a Democracia, ano 11, n. 42, jun - ago, 2007. A autora salienta ainda que por força dos arts. 93, IX, da CF e 92, parágrafo único, do CP, os efeitos da sentença condenatória devem ser motivadamente declarados. Logo, a suspensão do direito de votar, decorrente de condenação criminal transitada em julgado, deve ser declarada na sentença penal condenatória. Não pode surgir como consequiência automática da condenação. Seria então necessária uma declaração expressa e devidamente justificada da suspensão dos direitos políticos, ainda que se considere efeito secundário da sentença penal condenatória.
} 


\subsection{0 trabalho prisional}

Um tema extremamente sensível na execução penal consiste no direito ao trabalho prisional e seus consectários.

Inicialmente, estabelece a LEP em seu art. $28, \S 2^{\circ}$, que o trabalho do preso não está sujeito ao regime da Consolidação das Leis do Trabalho (CLT). Uma interpretação apressada e constitucionalmente desatualizada nos conduz a prontamente alijar o preso de todos os direitos trabalhistas contidos na CLT.

Uma visão redutora deve, porém, partir de outras premissas. A primeira delas esclarece que o fato de não se aplicar a CLT não significa que os presos estejam alijados de determinados direitos previstos em outros diplomas. A segunda premissa parte da necessidade de se interpretar o art. $28, \S 2^{\circ}$ à luz da própria Constituição de 1988 . A conjunção dessas duas premissas nos faz perceber que a Constituição Federal, ao estabelecer os direitos dos trabalhadores urbanos e rurais (art. $7^{\circ}$ da $\mathrm{CF}$ ), os destinou a todos, sem realizar qualquer distinção quanto aos presos. Necessário lembrar, mais uma vez, que se a própria Constituição não realizou a devida distinção, não pode uma norma infraconstitucional (anterior), ou mesmo seu intérprete, fazê-la.

Conclusão outra não há senão a de reconhecer aos presos todos os direitos contidos no art. $7^{\circ}$ da CF: décimo terceiro salário (inciso VIII), remuneração do trabalho noturno (eventualmente realizado) superior à do diurno (inciso IX) ou mesmo, por analogia, remição por trabalho noturno superior à do diurno, repouso semanal remunerado (inciso XV), gozo de férias anuais remuneradas com, pelo menos, um terço a mais do que o salário normal (XVII) e, por analogia, com um terço a mais de remição de pena, aviso prévio (inciso XXI) proporcional ao tempo de trabalho prisional, sendo no mínimo de trinta dias, a fim de que o preso tenha tempo para buscar outro trabalho na unidade, de modo a não interromper a fruição da remição.

A despeito da previsão legal de que o trabalho do preso não pode ser inferior a 3/4 (três quartos) do salário mínimo (ART. 29 da LEP), entendemos que o direito ao salário mínimo, conferido pela Constituição de 1988 indistintamente a todos, também deve beneficiar os presos. Além de constitucionalmente adequada, a elevação da remuneração oriunda do trabalho penitenciário também cumpriria mais eficazmente os próprios fins do pagamento (art. 29, $\left.\S 1^{\circ}\right)$ : indenização dos danos causados pelo crime, assistência à família do preso, 
pequenas despesas pessoais e ressarcimento ao Estado das despesas realizadas com a manutenção do condenado.

Outro consectário do trabalho penitenciário consiste no direito de atribuição de atividades que atendam às necessidades futuras do preso, bem como às oportunidades oferecidas pelo mercado (art. 32 da LEP). As regras mínimas para o tratamento de presos da ONU também se ocupam exaustivamente do tema: "Trabalho suficiente de natureza útil será dado aos presos de modo a conservá-los ativos durante um dia normal de trabalho" (item 71.3); "Tanto quanto possível, o trabalho proporcionado será de natureza que mantenha ou aumente as capacidades dos presos para ganharem honestamente a vida depois de libertados" (item 71.4); “Será proporcionado treinamento profissional em profissões úteis aos presos que dele tirarem proveito, especialmente aos presos jovens" (item 71.5); “A organização e os métodos de trabalho penitenciário deverão se assemelhar o mais possível aos que se aplicam a um trabalho similar fora do estabelecimento prisional, a fim de que os presos sejam preparados para as condições normais de trabalho livre" (item 72.1).

A realidade nos mostra que certos tipos de trabalho penitenciário (ex.: preso que possui por única função o estabelecimento de comunicação ou ligação entre a administração da prisão e o coletivo carcerário), apesar de necessários ao cotidiano prisional, são absolutamente distantes daqueles exercidos fora do estabelecimento prisional, deixando de preparar os presos para o enfrentamento do mercado de trabalho. Como utilidade, tais trabalhos somente propiciam remição ao detento. Uma postura pragmática defende a criação de postos de trabalho patrocinados por cooperativas ou pelas próprias empresas atuantes no meio livre.

\section{Da necessidade de construção de uma autêntica "teoria do tipo disciplinar"}

Em regra, os temas do direito penal mais explorados pelas publicações doutrinárias giram em torno da teoria do tipo penal. Tais discussões, porém, passam ao largo da execução penal, deixando de contagiá-la com a necessária reflexão acerca das faltas disciplinares. Em outras palavras, uma ancestral teoria do tipo penal mostrou-se absolutamente incapaz, até hoje, de fomentar uma correspondente "teoria do tipo disciplinar" na execução penal. Fundamental, portanto, que a execução penal rompa seu característico isolamento e receba tratamento integrado com os demais territórios do direito penal. Daí a proposição que ora formulamos, no sentido de criação de uma verdadeira "teoria do tipo disciplinar".

Esta teoria deve iniciar seu caminho compreendendo as bases, a conjuntura atual e, 
principalmente, os equívocos cometidos ao longo do extenso desenvolvimento da teoria do tipo penal.

Nesse sentido, deve afastar-se de um dos mais consagrados paradigmas do direito penal: o bem jurídico. Não há mais espaço para se conceber na execução penal a permanência de um ius puniendi disciplinar estatal, nem para se defender o império dos "bens jurídicos" ordem e disciplina carcerárias. Caso contrário, o direito subjetivo do Estado e a necessidade de incondicional proteção dos referidos "bens jurídicos" seriam fundamentos suficientes para a punição de todo e qualquer incidente carcerário, sobrepondo-se necessariamente aos direitos dos presos e legitimando um modelo autoritário e incompatível com o Estado Democrático de Direito.

O Estado, dessa forma, não pode ser encarado como titular de bens jurídicos, mas como provedor de segurança jurídica aos presos e à Administração Penitenciária, através da defesa da relação de disponibilidade que ambos possuem quanto a um valor ou interesse próprio.

A concepção pragmático-redutora, a que aludimos, busca estabelecer uma correção na idéia de ius puniendi disciplinar, bem como produzir uma nova compreensão do direito de execução penal, que passa a ser visto não mais como o fundamento do poder executivo, mas como o instrumento de limitação racional desse mesmo poder, tendo em vista a necessidade de redução máxima dos danos que a experiência penal causa ao indivíduo e, seguramente, à sociedade. Essa deve ser a visão norteadora de toda a "teoria do tipo disciplinar".

Diversamente da teoria do tipo penal, que se debruça sobre tipos dolosos, culposos e omissivos, a teoria do tipo disciplinar concentra sua análise nos tipos disciplinares dolosos, na medida em que somente faltas dolosas dos presos devem ser passíveis de sanção disciplinar. Evidentemente é possível que detentos cometam crimes culposos ou omissivos, mas, nesse caso, aplicar-se-á a própria teoria do tipo penal, não a teoria do tipo disciplinar.

Promovendo uma análise mais detalhada dos tipos disciplinares, entendemos que os mesmos possuem um aspecto subjetivo (tipo subjetivo - dolo) e um aspecto objetivo (tipo objetivo), sendo este último dividido em duas funções: função sistemática e função conglobante $^{7}$. Na função sistemática, analisa-se o tipo disciplinar isolado, ou seja, a mera fórmula que aparece na LEP ou nos regulamentos penitenciários Federal ou dos Estados (ex.:

\footnotetext{
${ }^{7}$ Seguimos, com as devidas adaptações à realidade da execução penal, o modelo de estrutura típica formulada por Eugenio Raul Zaffaroni. Nesse sentido, cf. ZAFFARONI, Eugenio Raul. Manual de derecho penal: parte general, Buenos Aires: Ediar, 2005.
} 
art. 50, inciso II da LEP: comete falta grave o condenado à pena privativa de liberdade que fugir).

No entanto, a análise isolada do tipo disciplinar não é suficiente para assegurar a existência de um conflito penitenciário (conflitividade penitenciária). Para tanto, a fórmula legal deve ser analisada em conjunto com as demais normas jurídicas, ou seja, deve estar conglobada com o restante das normas vigentes. Daí surge a noção de função conglobante, que traduz o conjunto de elementos do tipo disciplinar objetivo que devem ser levados em conta para se afirmar a conflitividade penitenciária.

A Função sistemática dos tipos disciplinares pode ser composta pelos seguintes elementos (alguns essenciais e outros acidentais): 1) elementos descritivos (são aqueles presentes na linguagem comum, científica ou jurídica, cujo significado independe de valorações éticas ou jurídicas. Ex.: art. 50, VII da LEP: “aparelho telefônico”); 2) elementos normativos (são elementos cujo significado depende de valorações éticas ou jurídicas para ser alcançado - ex.: art. 50, I da LEP: "subverter a ordem ou a disciplina”. São inconstitucionais, em razão de sua indeterminação e da insegurança jurídica que causam). 3) elementos normativos de recorte - aqueles que exigem que a ação se leve a cabo contra a vontade do sujeito passivo (ex.: art. 59, XVI, do Regulamento do Sistema Penal do Estado do Rio de Janeiro - Dec. 8.897/86: utilizar-se de objeto pertencente a companheiro, "sem a devida autorização"). Havendo o consentimento do sujeito passivo, não haverá tipicidade; 4) ação; 5) resultado (alteração no mundo exterior); 6) Nexo de causalidade - conforme a equivalência das condições (conditio sine qua non); 7) Sujeito ativo - preso; 8) Sujeito passivo - é o titular do interesse jurídico afetado.

A Função conglobante do tipo disciplinar, por sua vez, tem por objetivo constatar se houve lesividade na conduta do encarcerado. Por lesividade, entende-se a afetação significativa, por dano ou perigo concreto de dano, de um determinado interesse jurídico. Frise-se que o alcance da norma disciplinar não deve estar limitado por outras normas de igual ou superior hierarquia.

Apreciando agora o tipo disciplinar subjetivo (ou aspecto subjetivo do tipo disciplinar), podemos verificar que este possui o dolo como seu elemento essencial. Por dolo entende-se a vontade de realizar o tipo disciplinar objetivo, guiada pelo conhecimento. O dolo possui dois aspectos: aspecto cognitivo (requer o conhecimento efetivo e, de certa forma, real dos elementos descritivos, elementos normativos, previsão da causalidade e previsão do resultado) e aspecto conativo, composto pelo dolo direto (de primeiro grau, onde o sujeito quer diretamente o resultado, ou de segundo grau, em que o resultado é conseqüência 
necessária dos meios escolhidos pelo agente) ou pelo dolo eventual (quando o sujeito prevê a possibilidade de um resultado concomitante e inclui tal possibilidade no âmbito da vontade realizadora da conduta escolhida).

Conforme já salientado, o presente ensaio busca tão-somente propor bases para uma necessária e autônoma teoria do tipo disciplinar, não tendo a pretensão de esgotar o tema.

\section{Da necessidade de construção de uma "teoria da pena disciplinar"}

Não há como se estabelecer uma teoria do tipo disciplinar sem o correspondente desenvolvimento de uma teoria da pena disciplinar.

A importância de se delimitar os parâmetros das sanções disciplinares decorre fundamentalmente do fato de que estas, em muitos casos, possuem efeitos semelhantes aos da aplicação da própria pena. Perda de todos os dias remidos, eventual interrupção de prazos para a fruição de direitos, rebaixamento de comportamento (impossibilitando o preso de fruir dos direitos da execução penal pelo prazo de um ano), desclassificação do preso para o exercício de atividade laborativa, vedação de indulto ou comutação por condenação disciplinar nos últimos doze meses de cumprimento de pena, todos esses fatores trazem graves consequências para o status libertatis dos indivíduos, não sendo mais admissível que esta realidade permaneça obscurecida e sua teorização alijada dos embates doutrinários e jurisprudenciais.

Uma nova teoria da pena disciplinar não deve se deixar obscurecer pela secular e infecunda discussão acerca das finalidades da própria pena. Sua missão é, pelo contrário, adotar uma visão negativa da punição disciplinar, refutando os empregos retributivos ou utilitários desta.

Ao rechaçar a utilização retributiva da punição disciplinar, deixará de vê-la como um fim em si mesma, ou como uma ação reparadora do império da prisão frente a um ato de ameaça à sua estabilidade. Por outro lado, ao negar propósitos preventivos à punição, não mais a encarará como instrumento de intimidação (dissuasão) do coletivo carcerário, a fim de que todos se abstenham da prática de atos internos de insubordinação. Ou como meio de tutela forçada da "fidelidade" dos encarcerados em relação ao regramento carcerário. Ou ainda, como ferramenta de condicionamento do encarcerado à aceitação tanto de seu papel social, quanto das ordens a serem recebidas no futuro. 
Em outro trabalho ${ }^{8}$ já tivemos a oportunidade de detalhar as discussões acerca das faltas e penas disciplinares previstas na Lei de Execução Penal e no Regulamento do Sistema Penal do Estado do Rio de Janeiro, cumprindo-nos nesse ensaio examinar apenas alguns pontos específicos.

O primeiro deles consiste na corriqueira conjugação, por parte da autoridade penitenciária, entre o arts. 50, inciso VI e 39, incisos II e V da $\mathrm{LEP}^{9}$, de modo a punir por falta grave qualquer ato de desobediência às ordens recebidas.

Tal conjugação possui relevância na prática penitenciária, pois permite à autoridade penitenciária qualificar como falta grave, por exemplo, o porte de objetos não permitidos. $\mathrm{O}$ raciocínio empregado é o de que possuir objeto não permitido significaria, na verdade, desobedecer à ordem recebida no sentido de não possuí-lo, sendo assim cabível a imposição de sanção por falta grave.

Absolutamente equivocado tal raciocínio. Caso prevalecesse esse entendimento, cumpre lembrar que a amplitude sancionatória da autoridade seria ilimitada, uma vez que todas as faltas médias ou leves representariam na verdade faltas graves, já que estariam sendo desobedecidas as ordens de não praticá-las ${ }^{10}$.

Outro aspecto a ser considerado na prática da execução penal diz respeito a atos de desrespeito praticados entre companheiros de cárcere. Tal conduta recebe comumente sanção por falta grave, partindo do pressuposto de que qualquer ato de sublevação merece exemplar castigo. Nesse caso, a necessidade preventiva de tal reprimenda acaba, pois, violando a própria legalidade das penas disciplinares. Isso porque o ato de desrespeito praticado em relação a um companheiro de cárcere não é taxativamente previsto como falta grave. $\mathrm{O}$ inciso VI do art. 50 da LEP somente considera falta grave o descumprimento dos deveres previstos nos incisos II e $\mathrm{V}$ do art. 39. O dever de urbanidade e respeito no trato com os demais condenados encontra-se previsto, no entanto, no inciso III o art. 39 da LEP, não configurando falta grave.

Em uma nova perspectiva redutora de danos da execução penal, a punição das faltas tentadas com as mesmas penas das consumadas, promovida pelo art. 49, parágrafo único, da LEP, é outro tema que merece a necessária adequação constitucional. O desrespeito aos

\footnotetext{
${ }^{8}$ ROIG, Rodrigo Duque Estrada. Direito e Prática Histórica da Execução Penal no Brasil. Rio de Janeiro: Ed. Revan, 2005.

${ }^{9}$ Art. 50. Comete falta grave o condenado à pena privativa de liberdade que: VI - inobservar os deveres previstos nos incisos II e V, do artigo 39, desta Lei. Art. 39. Constituem deveres do condenado: II - obediência ao servidor e respeito a qualquer pessoa com quem deva relacionar-se; $\mathrm{V}$ - execução do trabalho, das tarefas e das ordens recebidas.

${ }^{10}$ De salientar que o porte de objeto ou valor, além do regularmente permitido, configura falta de natureza média, conforme o disposto no art. 59, XI, do Regulamento do Sistema Penal do Estado do Rio de Janeiro (Dec. 8.897/86).
} 
princípios da proporcionalidade e razoabilidade mostra-se evidente nesse trecho da lei penal executiva.

Como se não bastasse, se empreendermos uma análise sistêmica da legislação criminal brasileira, verificaremos o paradoxo criado pela LEP ao equiparar faltas disciplinares tentadas e consumadas. Assim procedendo, o legislador atribuiu à falta disciplinar gravidade maior do que aquela verificada nas próprias contravenções penais. Isso porque o art. $4^{\circ}$ da Lei de Contravenções Penais é categórico ao dispor que não é punível a tentativa de contravenção. Não há como se justificar de maneira lógica e racional o fato de ser impunível a tentativa de contravenção e, ao mesmo tempo, serem equiparadas as faltas graves tentadas e consumadas. Mais uma vez razões de ordem preventiva sobrepõem-se à constitucionalidade. Em nome da devida proporcionalidade, deveria ser igualmente impunível a tentativa de falta disciplinar.

Alternativamente, defende-se a necessidade de se estabelecer expressa previsão legal de abrandamento da sanção pela falta tentada, ou ainda, de se considerar a tentativa de falta disciplinar como falta média e não falta grave $\mathrm{e}^{11}$.

A ignorância ou a errada compreensão da norma disciplinar por parte dos presos também constitui tema de merecida reflexão. Apesar de inexistir na Lei de Execução Penal dispositivo expresso sobre o assunto, seguindo um juízo de proporcionalidade entendemos que no caso de ignorância ou de errada compreensão da norma disciplinar, quando escusáveis, a pena disciplinar pode deixar de ser aplicada. Essa é a previsão legal contida no art. $8^{\circ}$ da Lei de Contravenções Penais, quando faculta a não aplicação da pena por contravenção quando o autor do fato padece de escusáveis ignorância ou errada compreensão da lei. Por analogia, e considerando a maior gravidade ontológica da contravenção, tal dispositivo deve permear a análise das faltas disciplinares.

Importante frisar, em socorro a este argumento, que na prática penitenciária é bastante incomum haver qualquer ciência ao apenado do conteúdo das normas disciplinares, a despeito do próprio art. 46 da LEP, que exige que o condenado ou denunciado, no início da execução da pena ou da prisão, seja cientificado das normas disciplinares. Descumprindo o Estado uma obrigação legal sua, não poderá exigir do preso o cumprimento de um dever dela correspondente.

O retorno espontâneo do preso após evasão é também objeto de controvérsia. Sobre essa questão, o Superior Tribunal de Justiça já manifestou entendimento de que o fato de

\footnotetext{
${ }^{11}$ Nos autos do Agravo de Execução n. 241.802-3/98, o TJ/SP adotou essa tese, utilizando para tanto dois fundamentos: o primeiro no sentido de que o art. 49, parágrafo único, da LEP diz respeito às faltas médias e leves, e não às graves, que foram previstas no art. 50 da LEP. Como segundo fundamento, asseverou que a punição da tentativa com a pena da falta consumada se refere apenas às infrações administrativas.
} 
haver retornado ao presídio, espontaneamente, não desconstitui a falta grave cometida pelo sentenciado, afigurando-se irrelevante tal iniciativa (HC n. 37236/SP, julgado em 6/12/2004). Há ainda pronunciamento judicial no sentido de que o retorno espontâneo com pequeno e justificado atraso na reapresentação não configura falta grave (RT 766/698). Entendemos acertado esse último pronunciamento, em caso de pequeno atraso do apenado.

Problemática maior reside, no entanto, quando o retorno espontâneo se dá após expressivo decurso de tempo. Para a solução do caso, entendemos correto empreender uma analogia aos arts. 16 e 65, III, "b" do CP. O art. 16 do CP trata da figura do arrependimento posterior, estabelecendo que nos crimes cometidos sem violência ou grave ameaça à pessoa, reparado o dano ou restituída a coisa, até o recebimento da denúncia ou da queixa, por ato voluntário do agente, a pena será reduzida de um a dois terços. Por sua vez, o art. 65, III, "b”, do CP dispõe ser circunstância que atenua a pena ter o agente procurado, por sua espontânea vontade e com eficiência, logo após o crime, evitar-lhe ou minorar-lhe as conseqüências, ou ter, antes do julgamento, reparado o dano.

Ambos os dispositivos conferem tratamento penal mais brando ao agente que voluntariamente repara ou minora as conseqüências de seu ato. Não se mostra razoável permitir tal benefício em âmbito penal e refutá-lo em sede penitenciária. Desse modo, perfilhamos o entendimento de que nas fugas cometidas sem violência ou grave ameaça à pessoa, o retorno voluntário e anterior ao recebimento da parte disciplinar pelo juízo da execução não pode configurar falta grave. Consistiria no máximo falta média.

Diante da necessidade de se interpretar o ordenamento penal de forma ampla, sistemática e redutora, todos os benefícios legais, previstos ou não na Lei de Execução Penal, devem ser incorporados à execução da pena.

Perseguindo esse escopo, entendemos que seria medida extremamente salutar uma alteração legislativa que passe a reconhecer a possibilidade de substituição da pena de isolamento disciplinar por uma medida restritiva, em moldes análogos ao estabelecido pelo art. 44 do CP. Assim, em caso de falta disciplinar praticada sem violência ou grave ameaça e se as circunstâncias indicarem que essa substituição seja suficiente ${ }^{12}$, poderiam a autoridade administrativa ou o juízo da execução substituir o isolamento disciplinar por uma medida de interdição temporária de certos direitos do apenado (ex.: suspensão de regalias).

\footnotetext{
${ }^{12}$ Em virtude de sua inconstitucionalidade, discordamos que a reincidência possa obstar a substituição da pena privativa de liberdade por restritiva de direitos. Consequentemente, não a incluímos entre os requisitos para uma eventual substituição da pena disciplinar por uma medida restritiva de direitos.
} 
Tal medida teria o condão de romper com a inconstitucionalidade verificada no sistema de punições da LEP, que possibilita a injunção concomitante de uma pena de privação de liberdade (isolamento) e de uma pena restritiva de direitos (suspensão de visitas).

Outras importantes medidas a serem incorporadas na Lei de Execução Penal consistem na possibilidade de suspensão condicional da execução da sanção disciplinar ${ }^{13}$, suspensão condicional do processo administrativo disciplinar (em moldes análogos ao previsto no art. 89 da Lei n. 9.099/95), revisão disciplinar (analogamente ao disposto nos arts. 621 e seguintes do CPP) e reabilitação disciplinar (como se dá nos arts. 93 e seguintes do CP), bem como a previsão de circunstâncias atenuantes da pena disciplinar (como se verifica no art. 65 do $\mathrm{CP}$ ) e de causas legais de extinção da punibilidade disciplinar (analogamente ao disposto no art. 107 do CP).

Inovadora também a criação do instituto do "livramento condicional cautelar", medida esta utilizada tanto para beneficiar presos cujos pleitos de indulto encontram-se há muito tempo pendentes de apreciação judicial, quanto para beneficiar presos contemplados com o regime aberto de pena, mas que se vêem impossibilitados de fruir seu direito por ausência de vaga em casa de albergado. Esse último caso não deveria ensejar a possibilidade de prisão albergue domiciliar, mas sim de livramento condicional cautelar, por ser medida mais benéfica ao apenado ${ }^{14}$.

Quanto ao concurso de faltas disciplinares, entendemos que a adoção de uma perspectiva redutora é contrária ao entendimento hoje predominante (de que no silêncio da lei, as sanções devem ser cumpridas progressivamente, salvo se for possível o cumprimento simultâneo $)^{15}$.

Salvo melhor juízo, a conclusão de que no silêncio da lei as sanções devam ser cumpridas progressivamente parte de uma premissa perversa e antidemocrática. $\mathrm{Na}$ verdade, no silêncio da lei, deve ser empregada a analogia, evidentemente com o arts. 70 e 71 do CP, fazendo com que passemos a admitir o "concurso formal de faltas" e a "falta continuada".

Cumpre salientar ainda que, igualmente em um sentido redutor, defendemos a tese de que se um mesmo fato constitui duas faltas, a falta mais grave deve consumir a menos grave.

\footnotetext{
13 A suspensão condicional da execução da sanção disciplinar é medida contemplada pelo arts. 71 e 72 do Regulamento do Sistema Penal do Estado do Rio de Janeiro (Dec. 8.897/86). Art. 71: “A execução da sanção disciplinar aplicada poderá ser suspensa condicionalmente por seis meses, quando, a critério do diretor do estabelecimento, as circunstâncias, a gravidade e a personalidade do agente autorizem a presunção de que não voltará a praticar faltas"; Art. 72 - Se, durante o período de suspensão condicional, o punido não cometer falta, extinguir-se-á a punibilidade.

${ }^{14}$ Esse foi o entendimento adotado pelo STJ na decisão do habeas corpus n. 26537/SP.

${ }^{15}$ Nesse sentido, MIRABETE, Julio Fabbrini. op. cit. p. 141.
} 
De qualquer forma, todas as medidas supramencionadas serão pouco eficazes no processo de construção de uma teoria da pena disciplinar se as faltas disciplinares graves não estiverem incluídas no rol de competências dos Juízos de Execuções.

Incluídas nesse novo paradigma interpretativo estariam, portanto, as normas contidas nos arts. 53 a 60 da LEP, mas, sobretudo, aquela constante do art. 47 do mesmo diploma. Esta dispõe que "o poder disciplinar, na execução da pena privativa de liberdade, será exercido pela autoridade administrativa conforme as disposições regulamentares". Submetida ao crivo da jurisdicionalização constitucional, esta norma deve passar a ser interpretada no sentido de que apenas o poder de executar a sanção disciplinar poderá ser exercido pela autoridade administrativa. Não o poder de julgar as faltas.

Tal paradigma visa ao reconhecimento dos princípios da judicialização da execução penal (explicitados pelos arts. $65^{16}$ e $194^{17}$ da LEP e pelo art. $5^{\circ}$, inciso XXXV ${ }^{18}$, da Constituição de 1988), da imparcialidade (se o juiz não pode exercer jurisdição no processo em que for parte ou diretamente interessado no feito ${ }^{19}$, a autoridade administrativa tampouco poderá julgar as faltas disciplinares dos presos, pois no cotidiano carcerário a Administração Penitenciária ostenta autêntico caráter de parte), da indisponibilidade da jurisdição (a disponibilidade do exercício da atividade jurisdicional, por ser de caráter atípico, somente deveria se justificar nas hipóteses expressamente previstas na Constituição, o que não se verifica), do devido processo legal, contraditório e ampla defesa e da igualdade ${ }^{20}$.

Também a título propositivo, um novo procedimento deveria ser adotado no julgamento das faltas disciplinares, notadamente as graves. Assim posto, após a conclusão do inquérito disciplinar, com a colheita probatória preliminar, os diretores dos estabelecimentos

\footnotetext{
${ }^{16}$ Art. 65. A execução penal competirá ao Juiz indicado na lei local de organização judiciária e, na sua ausência, ao da sentença.

17 Art. 194: o procedimento correspondente às situações previstas nesta Lei será judicial, desenvolvendo-se perante o Juízo da execução.

${ }^{18}$ Art. 5º XXXV: A lei não excluirá da apreciação do Poder Judiciário lesão ou ameaça a direito.

19 252, inciso IV, do CPP: O juiz não poderá exercer jurisdição no processo em que: IV - ele próprio ou seu cônjuge ou parente, consangüíneo ou afim em linha reta ou colateral até o terceiro grau, inclusive, for parte ou diretamente interessado no feito.

${ }^{20}$ Diante da necessidade de adequar a normatização penitenciária à Constituição de 1988, o governo Federal editou o Regulamento Penitenciário Federal (Decreto 6.049/2007), estabelecendo expressamente em seu art. 49 que cabe à autoridade judicial a aplicação das sanções disciplinares referentes às faltas graves. Tal medida, se corretamente adotada, tem o condão de assegurar o legítimo direito dos "presos federais" à jurisdição, garantindo assim que seus processos executivos sejam regidos pela formalidade de procedimentos, ao contrário do que se daria em âmbito exclusivamente penitenciário, caracterizado pela informalidade ritualística e pela flexibilização de direitos e garantias. Se por um lado o Regulamento Federal finalmente reconheceu a jurisdicionalização da análise de faltas graves, por outro fez surgir uma grave discrepância entre o tratamento conferido a presos "federais" e "estaduais". Enquanto os primeiros passaram a se atrelar ao juízo da execução, os presos vinculados aos regulamentos penitenciários estaduais, em semelhantes situações disciplinares, continuam submetidos ao império da administração, em evidente violação ao princípio da isonomia.
} 
penais remeteriam os procedimentos aos Juízos das Varas de Execuções Penais dos Estados, para que estes, após a resposta preliminar do acusado, procedessem à análise da viabilidade da instauração do processo disciplinar.

Nos mesmos moldes do art. 397 do Código de Processo Penal, o juiz da execução poderia então absolver sumariamente o acusado quando verificasse a existência manifesta de causa excludente da ilicitude do fato, a existência manifesta de causa excludente da culpabilidade disciplinar do agente, quando concluísse que o fato narrado evidentemente não constitui falta disciplinar, ou ainda, quando estivesse extinta a punibilidade disciplinar do agente (ex.: prescrição da falta).

Também por analogia ao art. 399 do CPP, inexistindo causa suficiente para a absolvição sumária do acusado e após recebida a parte disciplinar, o juiz designaria dia e hora para a audiência, ordenando a intimação do acusado, de seu defensor e do Ministério Público.

$\mathrm{Na}$ audiência de instrução e julgamento disciplinar, proceder-se-ia à tomada de declarações do agente penitenciário formulador da parte disciplinar, à inquirição das testemunhas arroladas pela acusação e pela defesa, nesta ordem, bem como aos eventuais esclarecimentos dos peritos, às acareações e ao reconhecimento de pessoas e coisas, interrogando-se, em seguida, o acusado.

Produzidas as provas, o Ministério Público e, a seguir, o acusado poderiam então, ao final da audiência una, requerer diligências cuja necessidade se originasse de circunstâncias ou fatos apurados na instrução disciplinar (analogia ao art. 402 do CPP).

Não havendo requerimento de diligências, ou sendo indeferido, seriam oferecidas alegações finais orais, respectivamente, pela acusação e pela defesa, proferindo o juiz, a seguir, sentença disciplinar (art. 403 do CPP, por analogia).

Enfim, a adoção de um procedimento judicial e definido para o julgamento das faltas disciplinares constituiria significante instrumento formal de contenção do poder punitivo estatal, em sede de execução da pena.

\section{Conclusão}

O primeiro quarto de século da Lei de Execução Penal nos trouxe algumas lições. Se por um lado evidenciou algumas práticas e dispositivos eficazes, também tornou clara a deficiência prática de certas normas e órgãos da execução, cabendo-nos, quanto a estes, formular uma opção político-criminal: revê-los ou fomentá-los. 
Certo é que não há mais espaço para vermos o direito da execução penal como fundamento do poder executivo, mas como ferramenta de limitação racional desse mesmo poder. Também não é mais concebível analisarmos a Lei de Execução Penal de maneira isolada, sem cotejá-la com a Constituição de 1988, o Código Penal, o Código de Processo Penal e os tratados e convenções internacionais sobre o tema.

Enfim, estas são, a nosso ver, úteis e pragmáticas formas de se tornar a LEP mais racional, redutora de danos e capaz de devolver à execução da pena alguns de seus ideários esquecidos: humanidade, justiça e dignidade.

\section{REFERÊNCIAS:}

ALMEIDA, Angélica de Maria Mello de. Notas sobre o Direito de Votar do Preso. In: Boletim da Associação dos Juízes para a Democracia, ano 11, n. 42, jun - ago, 2007.

CARVAlHO, Salo. Teoria Agnóstica da Pena. O Modelo Garantista de Limitação do Poder Punitivo. In:VVAA, Crítica à Execução Penal, Salo de Carvalho(org.), Rio de Janeiro: Lumen Juris, 2002.

CINTRA JUNIOR, Dyrceu Aguiar. A Jurisdicionalização do Processo de Execução Penal: $O$ contraditório e a Ampla Defesa. Revista Brasileira de Ciências Criminais. No 9. São Paulo:Revista dos Tribunais, 1995.

FELLINI, Zulita (Dir.). Derecho de ejecución penal. $1^{\text {a }}$ ed., Buenos Aires: Hammurabi, 2006.

LOPES JUNIOR, Aury. A Instrumentalidade Garantista no Processo de Execução Penal. In: VVAA, Crítica à Execução Penal. Salo de Carvalho (org.), Rio de Janeiro: Lumen Juris, 2002.

MIOTTO, Armida Bergamini. Curso de Direito Penitenciário. Vol.II. São Paulo: Saraiva, 1975.

MIRABETE, Julio Fabbrini. Execução Penal. $9^{a}$ ed., São Paulo: Ed. Atlas, 2000.

RODRIGUES, Anabela Miranda. Novo Olhar sobre a Questão Penitenciária. São Paulo: Editora Revista dos Tribunais, 2001. 
ROIG, Rodrigo Duque Estrada. Direito e Prática Histórica da Execução Penal no Brasil. Rio de Janeiro: Ed. Revan, 2005.

SCHMIDT, Andrei Zenkner. Direitos, Deveres e Disciplina na Execução Penal. In: VVAA, Crítica à Execução Penal. Salo de Carvalho (org.), Rio de Janeiro: Lumen Juris, 2002.

ZAFFARONI, Eugenio Raul. Manual de derecho penal: parte general, Buenos Aires: Ediar, 2005. 